\title{
ZRÓŻNICOWANIE ŚCIEŻEK TRANSFORMACJI KRAJÓW EUROPY ŚRODKOWO-WSCHODNIEJ Z PERSPEKTYWY WSPÓLCZESNYCH TEORII EKONOMICZNYCH
}

\begin{abstract}
Streszczenie
Zainicjowany ponad ćwierć wieku temu proces transformacji ustrojowej krajów byłego bloku wschodniego miał charakter bezprecedensowy. Wyjaśnienie jego wymiaru ekonomicznego - możliwych i ostatecznie obieranych dróg przejścia od gospodarki nakazowo-rozdzielczej do gospodarki rynkowej - już przez samą tę bezprecedensowość, ale i niezwykła złożoność stanowiło i wciąż stanowi wyzwanie dla nauk ekonomicznych. Celem artykułu jest ocena, w jakiej mierze współczesna ekonomia poradziła sobie z tym wyzwaniem i próba uzasadnienia tezy, iż przy objaśnianiu zróżnicowanych trajektorii rozwojowych krajów transformacji i tłumaczeniu przyczyn osiaganych na tym polu sukcesów (lub ich braku) zdecydowanie bardziej adekwatne okazały się koncepcje stworzone przez reprezentantów szkół leżących na obrzeżach lub poza głównym nurtem badań ekonomicznych.
\end{abstract}

Słowa kluczowe: trajektorie rozwojowe, nowa ekonomia instytucjonalna, ekonomia ewolucyjna, transformacja ustrojowa, Europa Środkowo-Wschodnia

\section{DIVERSITY OF TRANSITION PATHS IN CENTRAL AND EASTERN EUROPE IN LIGHT OF CONTEMPORARY ECONOMIC THEORIES}

\section{Summary}

The process of systemic transformation in the countries of the former Eastern Bloc, spearheaded about a quarter of a century ago, was unprecedented in the economic history of the world. Its economic dimension - the available, and ultimately chosen, paths of transition from socialism to market economy - has challenged economic sciences. The challenge has been all the greater not only because of the novelty of the phenomenon, but also because of its unusual complexity. The paper aims to assess to what extent contemporary economics has succeeded in responding to this challenge and to prove that the concepts proposed by the representatives of schools from the margin of, or beyond, the mainstream economics turn out to be significantly more appropriate for explaining the diversity of transformation paths and elucidating the reasons behind the achievements (or lack thereof) of some countries.

Key words: path dependence, new institutional economics, evolutionary economics, transition, Central and Eastern Europe (CEE)

DOI: $10.15290 /$ ose.2015.01.73.02

${ }^{1}$ Dr Joanna Dzionek-Kozłowska - Wydział Ekonomiczno-Socjologiczny, Uniwersytet Lódzki, Instytut Ekonomii, Katedra Historii Myśli Ekonomicznej i Historii Gospodarczej; e-mail: jdzionek@uni. lodz.pl. 


\section{Wstęp}

Zainicjowany ponad ćwierć wieku temu proces transformacji ustrojowej państw byłego bloku wschodniego, mający przywrócić lub ustanowić w tych krajach ład demokratyczny i zasady gospodarki wolnorynkowej, miał charakter bezprecedensowy. Już sam ten fakt oznacza, iż wyjaśnienie wymiaru ekonomicznego tych przemian stało się dla nauk ekonomicznych wyzwaniem. Wyzwaniem tym poważniejszym, że proces transformacji dokonywał się na wielu płaszczyznach i co za tym idzie - był niezwykle złożony. Trudności rodziło wytłumaczenie jego przebiegu oraz przyczyn zróżnicowania obieranych przez poszczególne kraje dróg przechodzenia od gospodarki nakazowo-rozdzielczej do wolnorynkowej. Jednakże równie ważny, a początkowo może nawet ważniejszy, problem stanowiło wskazanie podstaw do formułowania i dostarczenia wskazówek dotyczących sposobu dokonania reform gospodarczych, tak żeby były one skuteczne, trwałe i wprowadzane przy możliwie najniższym koszcie ekonomicznym i społecznym.

Wprawdzie w naukach ekonomicznych przez lata toczyła się (chwilami bardzo żarliwa) dyskusja nad wadami i zaletami kapitalizmu i socjalizmu², a pokaźne grono autorów poświęciło wiele energii na dowiedzenie wyższości jednego lub drugiego modelu. Dzięki temu pożądane czy po prostu opisywane modele były przedstawiane względnie jasno. Natomiast zdecydowanie mniejszą uwage poświęcano na przestawienie metod ich wdrożenia. O ile przemiana systemu gospodarczego od kapitalizmu do socjalizmu była przedmiotem refleksji teoretycznej (w sposób mniej czy bardziej ogólny wypowiadali się na ten temat dziewiętnastowieczni socjaliści utopijni i Karol Marks), o tyle transformacja w kierunku odwrotnym - już nie. Tymczasem, pomimo braku wsparcia teoretycznego, wprowadzenie w życie zamysłu transformacji ustrojowej pociagało za sobą konieczność podejmowania szeregu bardziej czy mniej szczegółowych decyzji dotyczących: sposobu, metod i kolejności wprowadzania zmian. Z kolei, z punktu widzenia otoczenia międzynarodowego, a przede wszystkim organizacji międzynarodowych i państw zachodnich, konieczne stało się wypracowanie zasad pozwalających rozstrzygać, czy i na jakich warunkach udzielać wsparcia, znajdującym się częstokroć w katastrofalnej kondycji gospodarczej, krajom tzw. realnego socjalizmu. Jednocześnie podmioty te stały się w ten sposób swego rodzaju zewnętrznymi recenzentami procesu reform i aktywną stroną mogącą w zasadniczy sposób wpłynąć na ich sukces.

Celem artykułu jest dokonanie oceny, w jakiej mierze ekonomia poradziła sobie z wyjaśnieniem ekonomicznego wymiaru transformacji oraz próba uzasadnienia tezy, iż do objaśniania zróżnicowanych trajektorii rozwojowych krajów transformacji i wytłumaczenia przyczyn osiaganych na tym polu sukcesów (lub ich braku) bardziej adekwatne okazały się koncepcje stworzone na gruncie szkół leżących na obrzeżach lub poza głównym nurtem badań ekonomicznych.

\footnotetext{
2 Jednym z jej najbardziej burzliwych etapów był słynny spór o racjonalność gospodarki socjalistycznej pomiędzy reprezentantami ekonomii neoklasycznej: F. M. Taylorem, A. P. Lernerem i O. Lange a przedstawicielami szkoły austriackiej, L. von Misesem i F. A. von Hayekiem [zob. więcej: Godłów-Legiędź, 1989; Kostro, 2001].
} 


\section{Proces transformacji ustrojowej a ekonomia ortodoksyjna}

Na przełomie lat osiemdziesiątych i dziewięćdziesiątych XX wieku ortodoksyjna teoria ekonomii była niemal bezradna wobec analizy procesu transformacji ustrojowej krajów byłego bloku wschodniego. Zainteresowania badawcze większości ekonomistów neoklasycznych ${ }^{3}$ koncentrowały się wokół sytuacji, w których mechanizm alokacji zasobów był oparty przede wszystkim (lub nawet wyłącznie ${ }^{4}$ ) na działaniu rynku. Dociekano, w jakich warunkach tego rodzaju system osiaga równowagę bądź w jaki sposób przebiega proces dochodzenia do równowagi, ale przy przyjętych odgórnie założeniach dotyczących m.in. stałości struktury instytucjonalnej i racjonalności podmiotów gospodarczych. Jednym z nielicznych, i wobec tego tym bardziej wartych wspomnienia, wyjątków była teoria projektowania mechanizmów alokacyjnych ${ }^{5}$, choć i w tym przypadku pokazywano raczej możliwe rozwiązania instytucjonalne i różnice pomiędzy nimi niż optymalną drogę przejścia od rozwiązania gorszego do lepszego.

Tymczasem jednym z podstawowych pytań zadawanych po dziś dzień przez badaczy i obserwatorów procesu transformacji jest kwestia: dlaczego jednym krajom udało się odnieść na tym polu sukces, a innym nie ${ }^{6}$. W tym miejscu trzeba jednak zaznaczyć, że nawet jeśli ograniczymy się do perspektywy czysto ekonomicznej, sukces ten można postrzegać w co najmniej dwojaki sposób: (1) w kategoriach zbliżenia struktury systemu ekonomicznego do jakiegoś zakładanego czy idealnego modelu gospodarki kapitalistycznej/wolnorynkowej lub (2) poprzez zestawienie wyników osiąganych przez dany

3 Trzeba zaznaczyć, że określenie ekonomia neoklasyczna nie jest tożsame z pojęciem ekonomia ortodoksyjna, czy tym bardziej ekonomia głónnego nurtu. Co gorsza, termin ten jest do tego stopnia nadużywany i nieprecyzyjny, że już w połowie lat osiemdziesiatych XX wieku T. Aspromourgos [Aspromourgos, 1986] przekonywał o konieczności wyraźnego, także terminologicznego, rozgraniczenia określanych w ten sposób szkól, a na przełomie mileniów D.C. Colander [Colander, 2000] wzywał do dokonania - jak sam to nazwał - swoistej „terminazji” mającej prowadzić do całkowitego odrzucenia posługiwania się tą nazwa. Jak dotąd, postulat Colandera nie odniósł zakładanego przez autora skutku, choć niewatpliwie przyczynił się do większej ostrożności w posługiwaniu się tym terminem i prób precyzowania, co dokładnie rozumiemy używając określenia ekonomia neoklasyczna. W tym miejscu autorka artykułu posługuje się nim dla oznaczenia jednego z głównych nurtów rozwijających się w ramach dwudziestowiecznej teorii ekonomii, który wyrastał z prac L. Walrasa i A. Marshalla, opierał się na indywidualizmie metodologicznym i koncentrował na problemach alokacji zasobów w systemie gospodarki wolnorynkowej.

${ }^{4}$ Takie podejście było właściwe m.in. dla nowych ekonomistów klasycznych czy przedstawicieli teorii realnego cyklu koniunkturalnego. Co więcej, reprezentanci tych nurtów tworzyli modele oparte na założeniu, że ceny są na tyle elastyczne, iż rynki opróżniają się w sposób ciągły [Snowdon, Vane, Wynarczyk, 1998; Snowdon, Vane, 2005, s. 223-224, 230-232].

${ }_{5}^{5}$ Dla rozwoju tej koncepcji fundamentalne znacznie miały prace Leonida Hurwicza [Hurwicz, 1973; Hurwicz, 1979].

${ }^{6}$ Problem ten można potraktować jako szczególną wersję bardziej ogólnego, a zarazem fundamentalnego dla ekonomii i nie tracącego na aktualności pytania o przyczyny bogactwa jednych narodów i ubóstwa innych. Poza oczywistym w tym kontekście odwołaniem do Bogactwa narodón A. Smitha, jako świadectwo zainteresowania tą kwestią w czasach nam współczesnych, anonsowane już nawet na poziomie samych tytułów, można przywołać prace: M. Olsona, The Rise and Decline of Nations: Economic Growth, Stagflation, and Social Rigidities [Olson, 1982], D. Landesa Bogactwo i nedza narodów. Dlaczego jedni sq tak bogaci, a inni tak. ubodży [Landes, 1998] czy wydaną przed dwoma laty ksiazżę D. Acemoglu i J.A. Robinsona Why Nations Fail. The Origins of Power, Prosperity and Poverty [Acemoglu, Robinson, 2012, wyd. polskie 2014]. 
kraj po pewnym czasie od rozpoczęcia reform z poziomem tych samych kategorii uzyskiwanych przed ich zainicjowaniem. W praktyce były stosowane oba podejścia przy czym początkowo, przy bardzo krótkiej perspektywie czasowej, z konieczności dominowało pierwsze $\mathrm{z}$ nich. W okresie bezpośrednio po zapoczątkowaniu transformacji ocenianie jej sukcesów na podstawie wyników makroekonomicznych nie było miarodajne, ponieważ głębokim zmianom strukturalnym we wszystkich krajach byłego bloku wschodniego towarzyszyła tzw. recesja transformacyjna. Poprzestawanie wyłącznie na ocenie dostatecznego „urynkowienia” gospodarki rodzi poważne wattpliwości ${ }^{7}$, lecz formułowanie ocen „poprawności” kierunku zmian było niezbędne i to nawet $\mathrm{z}$ perspektywy krótkookresowej zarówno z punktu widzenia samych reformatorów (decydentów i doradców), jak i dla instytucji międzynarodowych, które uzależniały od tych ocen przyznawanie bądź kontynuowanie udzielania pomocy finansowej.

Warto podkreślić, że ocenianie transformacji ustrojowej pod względem stopnia zbliżenia systemu gospodarczego do ideału gospodarki wolnorynkowej (w myśl zasady „więcej rynku - większy sukces”) bywa przedstawiane jako charakterystyczne dla neoklasycznej teorii ekonomicznej czy wręcz bazujące na niej. Mimo wszystko jest to o tyle niesłuszne, że - jak zostało to wskazane wcześniej - ekonomia neoklasyczna jako taka w zasadzie nie dawała podstaw do formułowania jakichkolwiek ocen przebiegu procesu transformacji czy tym bardziej przedstawiania recept. Inna rzecz, że tego rodzaju opinie bądź zalecenia formułowali natomiast ekonomiści postrzegani jako reprezentanci tego nurtu ${ }^{8}$. Wobec tego warto zaznaczyć, że ich przesłanką była jednak nie tyle teoria ekonomii, co wierność określonej doktrynie społeczno-gospodarczej i politycznej - liberalizmowi gospodarczemu lub/i libertarianizmowi ${ }^{9}$.

\footnotetext{
7 Zasadniczy problem wiąże się z faktem, iż w praktyce uznanie za cel urzeczywistnienia określonego ideału jest $z$ góry skazane na niepowodzenie i, co gorsza, może prowadzić do doktrynerstwa. Ponadto sprowadzenie sensu transformacji do budowy w krajach postsocjalistycznych systemu gospodarczego maksymalnie zbliżonego do modelu gospodarki wolnorynkowej byłoby nadmiernym uproszczeniem - wydaje się, że dążenie do zmiany fundamentów ustroju społeczno-gospodarczego wynikało w tych państwach raczej z potęgującego się przekonania o nieefektywności poprzedniego systemu i starań o wprowadzenie takiego, który pozwoliłby na rozwój gospodarczy i podniesienie standardu życia, niż z powszechnych starań o ucieleśnienie ideału gospodarki kapitalistycznej.

${ }^{8}$ Do najbardziej znanych należeli tu J. Sachs czy M. Friedman. Podejście to było również znamienne dla części organizacji międzynarodowych, udzielających wsparcia krajom postsocjalistycznym, a w szczególności dla MFW i Banku Światowego (zestaw podstawowych wytycznych, składających się na tego rodzaju politykę, zyskał miano tzw. konsensusu waszyngtońskiego), [Williamson, 1990; por. także Williamson, 2005, s. 195-206; Legiędź, 2013, s. 82-83].

9 Zastanawiające, a zarazem godne uznania jest to, że zwracając uwagę na zagrożenia związane z próbami wcielania w życie w krajach dawnego bloku wschodniego abstrakcyjnej wizji gospodarki wolnorynkowej (swego rodzaju „typu idealnego" kapitalizmu) J.K. Galbraith już w 1990 roku, czyli u progu transformacji, stwierdził, iż gdyby jakies gospodarki oparly sie na takiej koncepgij, to nie przetrwatyby. To, co jest oferowane, to konstrukcia ideologiczna, ketóra istnieje mytacznie w umystach, a zwtaszrza w nadriejach donatorów. Owa konstrukcja nie ma żadnego zwiazku z. reecrymistościa i jest tym, co gdrie indriej naspwatem prymityma ideologia [Galbraith, 1990, za: Wilkin, 1995, s. 8].
} 


\section{Transformacja ustrojowa $z$ perspektywy ekonomii ewolucyjnej i nowej ekonomii instytucjonalnej}

Przy poszukiwaniu odpowiedzi na pytania o przyczyny faktycznego przebiegu i zróżnicowania transformacji można odwołać się natomiast do takich teorii ekonomicznych, w przypadku których przyjmowane na gruncie ekonomii neoklasycznej założenie o niezmienności struktury instytucjonalnej jest uchylone, a zainteresowania badaczy koncentrują się na objaśnieniu jej ewolucji i wskazaniu czynników wpływających na jej przemiany. Tego rodzaju podejście było charakterystyczne dla ekonomistów ewolucyjnych i przedstawicieli nowej ekonomii instytucjonalnej ${ }^{10}$.

Ekonomia ewolucyjna koncentruje się na badaniu procesów rozwoju zachodzących na rożnych płaszczyznach życia gospodarczego przy założeniu, że zarówno reguły działania organizacji czy społeczeństw, jak i zasady kierujące postępowaniem jednostek ewoluuja ${ }^{11}$. Z punktu widzenia analizy transformacji szczególnie użyteczną koncepcja, zaproponowaną przez ekonomistów związanych z tym kierunkiem, wydaje się idea path dependence ${ }^{12}$. Samo pojęcie pojawiło się tuż przed rozpoczęciem procesu przemian ustrojowych $i$, jak nie trudno zgadnać, początkowo nie miało nic wspólnego $\mathrm{z}$ analizą tego procesu. W latach osiemdziesiatych XX wieku P. David i B. Arthur [David, 1985; Arthur, 1989] wprowadzili ja, by wytłumaczyć pojawianie się sytuacji, które z perspektywy ortodoksyjnej teorii ekonomicznej należało uznać za swego rodzaju paradoks, a mianowicie przypadków, w których dochodziło do upowszechniania się gorszych standardów pomimo istnienia innych, lepszych rozwiązan ${ }^{13}$. Zdaniem wskazanych wyżej badaczy, dla spełnienia się tego rodzaju scenariusza kluczowy był początkowy etap, na którym gorsze rozwiązanie (technologia) mogło uzyskać niewielką choćby przewagę, przy czym źródłem tej przewagi mogły być nawet pojedyncze, z pozoru nieistotne zdarzenia, jednostkowe wybory czy zwykły przypadek. W określonych warunkach ${ }^{14}$ sku- $^{-}$

${ }^{10}$ Ekonomia ewolucyjna bywa niekiedy klasyfikowana jako nurt zaliczany do nowej ekonomii instytucjonalnej [Maślak, 2000; Hodgson, 2007]. Należy również dodać, że założenie o stałości struktury instytucjonalnej nie jest utrzymane na gruncie teorii wyboru publicznego. W przeciwieństwie do dwu wymienionych w tekście nurtów - ekonomii ewolucyjnej i nowej ekonomii instytucjonalnej - analizy przedstawicieli Public Choice sa jednak poświęcone nie tyle procesom rozwoju tejże struktury, ile raczej przedstawieniu i wskazaniu konsekwencji określonych (istniejących i postulowanych) rozwiązań instytucjonalnych. Jednakże - co także warto podkreślić - już samo uchylenie założenia o stałości struktury instytucjonalnej zaowocowało stworzeniem przez reprezentantów teorii wyboru publicznego pewnych koncepcji, które rzucaja światło na przebieg procesu transformacji krajów postsocjalistycznych [szerzej patrz: Teoria nyboru publicznego. Głónne nurty i zastosowania, 2012, zwłaszcza s. 25-26, 124-125, 216-218, 233-234].

11 Dla rozwoju tego nurtu fundamentalne znaczenie ma praca R. Nelsona i S. Wintera An Evolutionary Theory of Economic Change [Nelson, Winter, 1982].

${ }^{12} \mathrm{~W}$ polskiej literaturze sformułowanie to jest tłumaczone najczęściej jako trajektorie/ ścię̇ki roz̧wojowe lub zależność ścię̇kowa [zob.: Dzionek-Kozłowska, 2010]. Na temat wykorzystania tej koncepcji do analizy procesu transformacji szerzej w: [Dzionek-Kozłowska, 2009].

$13 \mathrm{~W}$ literaturze ekonomicznej kanonicznego charakteru nabrał tu wskazany przez P. Davida przykład upowszechnienia się klawiatury typu QWERTY [David, 1985]. Z kolei D. J. Puffert [Puffert, 2004] zebrał szereg innych przykładów.

${ }^{14}$ David wymieniał tu jednoczesne wystąpienie: (1) tzw. współzależności technicznej, oznaczającej konieczność dostosowania przez nabywców posiadanego kapitału rzeczowego lub/i ludzkiego, (2) qua- 
mulowanym efektem jej zdobycia było wkroczenie branży na określoną „ścieżkę rozwoju" i dalsze umacnianie się danego standardu.

Mimo dość gwałtownej, choć możliwej do przewidzenia krytyki tej koncepcji ze strony przedstawicieli ekonomii ortodoksyjnej [m.in.: Leibowitz, Margolis, 1990; Liebowitz, Margolis, 1995], argumentacja Arthura i Davida bardzo szybko zyskała licznych zwolenników, a podobnych zależności zaczęto ponieważ w wielu innych sferach. „Podatnym gruntem” na jej zastosowanie okazały się także prowadzone z perspektywy nowej ekonomii instytucjonalnej analizy rozwoju i wzrostu gospodarczego. Na tym polu szczególnie istotne były publikacje D.C. Northa [North, 1990; North, 1991; North, 2010], który wykorzystał ideę Arthura i Davida jako komponent przedstawionej przez siebie teorii objaśniającej powody, dla których jednym społeczeństwom udaje się stworzyć warunki pozwalające na osiagnięcie wzrostu gospodarczego, a inne przez stulecia nie są w stanie wydobyć się ze stanu stagnacji15. Podstawowy, sformułowany przez niego wniosek można sprowadzić do twierdzenia, iż warunkiem niezbędnym długookresowego wzrostu gospodarczego jest istnienie takiego systemu instytucji formalnych i nieformalnych, który dostarczałaby podmiotom bodźców pobudzajacych je do większej efektywności. Problem w tym, że zmiana istniejącej matrycy instytucjonalnej, również ta w kierunku pożądanym z punktu widzenia stymulowania wzrostu gospodarczego, jest na ogół procesem trudnym i długotrwałym. Objaśniając przyczyny zastanawiającej trwałości struktur instytucjonalnych, North uznał, że i na tej płaszczyźnie może dojść do ugruntowania się „gorszego" rozwiązania, a prowadzący ku temu mechanizm wykazuje cechy charakterystyczne dla procesów typu path dependence. North dowodził bowiem, że mamy tu do czynienia z występowaniem (szczególnie pojętych) rosnących przychodów, które pojawiają się w konsekwencji istnienia sieciowych efektów zewnętrznych. Tego rodzaju efekty powstaja, ponieważ podmioty działające w ramach określonej matrycy instytucjonalnej będą odnosić korzyści, jeśli inni członkowie danej społeczności równocześnie będą respektować te same reguły gry. Co więcej, dla jednostek działających na podstawie określonej matrycy instytucjonalnej każda zmiana reguł będzie wiązać się z niebezpieczeństwem pogorszenia sytuacji, prawdopodobieństwem utraty nakładów poniesionych na tworzenie organizacji sprawdzających się w poprzednich warunkach oraz koniecznością poniesienia nakładów niezbędnych do przystosowania się do nowych okoliczności ${ }^{16}$. Wobec powyższego, obrona status quo przez jednostki przystosowane do funkcjonowania $\mathrm{w}$ danym systemie instytucjonalnym wydaje się być jak najbardziej zrozumiała.

si-nieprzechodniości inwestycji, czyli trudności odzyskania nakładów poniesionych na dokonanie tego rodzaju dostosowania prowadzącej do „zamknięcia” (ang. lock-in) innych możliwości oraz (3) zjawiska rosnących przychodów.

${ }^{15} \mathrm{Na}$ temat koncepcji D.C. Northa szerzej w: [Godłów-Legiędź, 2010, rozdz. 3.].

16 Odwołując się do koncepcji M. Olsona i posiłkując pojęciem dominującego interesu (ang. encompassing interest), podobne rozumowanie można także zastosować w odniesieniu do działań grupowych [Olson, 1992, s. 56]. Ciekawe uwagi na temat przebiegu procesu transformacji w Polsce, bazujące na tej koncepcji wraz z komentarzem dotyczącym wniosków sformułowanych przez samego Olsona, przedstawił J. Wilkin [Wilkin, 2012, s. 25-26]. 
Sposób, w jaki North posłużył się koncepcja path dependence przy analizie przemian zachodzących w sferze instytucji, w znacznej mierze wpłynął na wykorzystywanie jej przez badaczy transformacji ustrojowej krajów byłego bloku wschodniego ${ }^{17}$. Zgodnie z wymową rozważań D.C. Northa, wskazywano, iż budowanie nowych ram ustrojowych odbywa się na gruncie wcześniejszych rozwiązań instytucjonalnych i relacji społecznych. Punktem wyjścia było tu uznanie, że rdzeń każdej ludzkiej cywilizacji stanowi szczególny dla niej i wykształcony w toku jej rozwoju zestaw podstawowych wartości i wierzeń kształtujących: sposoby myślenia, instytucje, kody zachowania i komunikacji. Te głęboko zinternalizowane przez członków określonej cywilizacji wzorce formuja się na początkowym etapie jej rozwoju i w całym okresie jej istnienia mają charakter niemal niezmienny (zmieniają się bardzo wolno, na przestrzeni stuleci czy nawet tysiącleci). Sa to więc elementy, które przez wieki w zasadniczy sposób wpływaja na ludzkie zachowania i działania. Można zatem uznać, że tak rozumiane wzorce cywilizacyjne wyznaczają swego rodzaju ramy rozwojowe narodów i społeczeństw. Jeśli założymy, że stanowią one nieprzekraczalną w dłuższej perspektywie barierę dla możliwych kierunków ich rozwoju, można tu będzie mówić o występowaniu procesu typu path dependence: możliwe „ścieżki rozwoju” danego narodu są wyznaczone przez właściwy mu wzorzec cywilizacyjny. Nie oznacza to, że na gruncie danego wzorca cywilizacyjnego może wyrosnać tylko jedna, określona i tym samym zdeterminowana a priori forma organizacji życia: społecznego, gospodarczego i politycznego. Odwołanie się do koncepcji path dependence oznacza jedynie, że szanse na rozwinięcie i ugruntowanie się w danym społeczeństwie będą miały tylko takie struktury instytucjonalne, które pozostają w zgodzie z jego trwałymi parametrami cywilizacyjnymi. Rozwiązania sprzeczne z właściwym dla danego społeczeństwa wzorcem cywilizacyjnym zostana przez nie albo zmodyfikowane, albo odrzucone [Zukowski, 2005; Zweynert, Goldschmidt, 2006]. Do wprowadzenia obcych kulturowo instytucji może dojść jedynie wówczas, gdy zostaną one narzucone danemu społeczeństwu siłą i naciski te będą się utrzymywać przez bardzo długi czas (długi na tyle, aby doszło do modyfikacji wzorców przekazywanych kolejnym pokoleniom jako dziedzictwo kulturowe), [Kyriazis, Zouboulakis, 2005].

Umieszczenie w tak nakreślonej perspektywie procesu transformacji ustrojowej krajów Europy Środkowej i Wschodniej pociągnęło za sobą konieczność określenia, czy rozpoczęte ćwierć wieku temu przemiany maja charakter na tyle doniosły, by postrzegać je jako próbę zmiany fundamentów cywilizacyjnych czy raczej ewolucję dokonująca się w ramach istniejącego wzorca. Dla oceny wymiaru przemian związanych z procesem transformacji istotne jest również, jak postrzega się charakter wcześniejszych zmian związanych $z$ tworzeniem fundamentów społeczeństwa komunistycznego (zmiana wzorca czy zmiany w ramach wzorca?). W zamyśle twórców myśli socjalistycznej budowa tego ustroju miała doprowadzić do stworzenia od podstaw nowego, „lepszego” społeczeństwa, a rewolucja proletariacka miała zaowocować wkroczeniem na całkowicie nowa ,ścieżkę rozwojową”. Jednak w praktyce nowo tworzony system nie był, rzecz jas-

${ }^{17}$ Do dyskusji zresztą włączył się również i sam D. C. North [North, 2010, rozdz. 11.]. 
na, wprowadzany w swego rodzaju próżni instytucjonalnej, lecz na gruncie wyznaczanym przez wzorce właściwe dla cywilizacji panującej na obszarze, na którym go wdrażano.

Wziąwszy pod uwage zróżnicowanie kulturowe krajów Europy Środkowej i Wschodniej, zasadne wydaje się wyodrębnienie na tym obszarze co najmniej trzech kręgów cywilizacyjnych: kultury zachodniej (łacińskiej), kultury wschodniej (bizantyjskiej) oraz kultury orientalnej, choć w tym ostatnim przypadku wśród państw regionu w czystej formie występuje ona jedynie w Albanii ${ }^{18}$. W formowaniu, umacnianiu i przekazywaniu podstawowych wartości szczególnie istotną rolę odgrywają wierzenia religijne, stąd częstokroć wskazane modele cywilizacyjne charakteryzuje się przez wskazanie religii dominujących na obszarze ich obowiązywania. W cywilizacji zachodniej są to wartości krzewione przez zachodnie odłamy chrześcijaństwa (katolicyzm, protestantyzm), natomiast cywilizację wschodnią wiąże się z prawosławiem, a orientalną $\mathrm{z}$ islamem. Przy tego rodzaju porównaniach jako fundamentalne dla modelu zachodniego wskazuje się poszanowanie godności osoby ludzkiej, indywidualizm oraz uwypuklone w okresie oświecenia: racjonalizm i wolność jednostki. Z kolei dwa pozostałe modele łączy położenie nacisku na wartości wspólnotowe i będący ich konsekwencją: kolektywizm, zbiurokratyzowanie i tendencję do autorytarnej formy rządów [Huntington, 2008, s. 56, 63-64].

W badaniach poświęconych transformacji krajów Europy Środkowej i Wschodniej częstokroć zwraca się również uwagę na to, że przed okresem rozpoczęcia socjalistycznych eksperymentów model zachodni był wdrażany na obszarze wpływów Monarchii Habsburskiej i Prus, model wschodni na terenach podporządkowanych carskiej Rosji, zaś model orientalny - w sferze wpływów Imperium Osmańskiego [Zukowski, 2005, s. 312]. Jednak należy podkreślić, że fakt, iż dany obszar przez jakiś czas znajdował się w określonej strefie wpływów, nie przesądzał ostatecznie o zakorzenieniu się w społeczeństwie go zamieszkującym wartości promowanych przez dane mocarstwo $^{19}$.

Ujmując rzecz z takiej perspektywy, można uznać, że rewolucja październikowa zaowocowała stworzeniem wschodniej (bizantyjskiej) wersji socjalizmu, ze wszystkimi cechami charakterystycznymi dla tego wzorca cywilizacyjnego, a w Rosji - wbrew nadziejom dziewiętnastowiecznych teoretyków socjalizmu - tzw. realny socjalizm nie doprowadził ani do zniesienia rządów autorytarnych, ani do poszanowania wolności obywatelskich, ani do zlikwidowania wszechwładnego aparatu biurokratycznego. Jedna, oparta na tych elementach forma została zastapiona druga. Z tego względu wydaje się, że w przypadku Rosji i pozostałych krajów Europy Środkowej i Wschod-

18 Z tego względu niektórzy badacze biora pod uwage jedynie dwa pierwsze z wymienionych wzorców [Winiecki, 2004, s. 137-152; Winiecki, 2012; Zweynert, Goldschmidt, 2006, s. 899-900]. W krajach Europy Środkowej i Wschodniej, w których można dostrzec znaczące wpływy kultury orientalnej, czyli Bułgarii, Bośni i Hercegowiny, Macedonii, Mołdawii, Rumunii, Serbii czy Czarnogóry, mamy do czynienia ze ścieraniem się tych tradycji z wpływami cywilizacji wschodniej.

19 Za przykład może tu posłużyć utrzymanie się w kręgu cywilizacji zachodniej krajów nadbałtyckich, znajdujących się od XVIII wieku w strefie wpływów rosyjskich. 
niej, mieszczących się w ramach cywilizacji bizantyjskiej, wprowadzenie sowieckiego modelu socjalizmu należałoby interpretować jako dokonywanie zmian w ramach trajektorii rozwojowej cywilizacji wschodniej. Z kolei w przypadku krajów z obrębu cywilizacji zachodniej próbę tę można potraktować jako dążenie do siłowego wymuszenia zmiany „naturalnej”, zgodnej z właściwym im wzorcem cywilizacyjnym ścieżki rozwojowej [Zweynert, Goldschmidt, 2006, s. 906-909].

Okres socjalistycznych eksperymentów niewątpliwie odcisnął swoje piętno na zasadach, postawach i normach postępowania członków społeczeństw, w których usiłowano go wdrażać, lecz oszacowanie, jak głęboko sięga ten wpływ i jak bardzo okaże się on trwały jest nadal kwestią otwartą. Przedstawiane podejście można natomiast wykorzystać jako jedną z możliwych dróg wytłumaczenia sukcesów transformacyjnych krajów Europy Środkowej i Środkowo-Wschodniej mieszczących się w kręgu cywilizacji zachodniej (proces transformacji jako próba powrotu do wcześniejszej, przedsocjalistycznej „ścieżki”) ${ }^{20}$ i trudności czy wręcz fiasko transformacji w pozostałych państwach regionu (proces transformacji jako usiłowanie wytyczenia całkowicie nowego kierunku ich rozwoju).

Znaczenie instytucji dla szans rozwoju gospodarczego podkreślają również D. Acemoglu i J.A. Robinson [Acemoglu, Robinson, 2013] ${ }^{21}$, choć autorzy ci wykazują się jednocześnie dużo większym od Northa sceptycyzmem wobec akcentowania roli czynników kulturowych ${ }^{22}$. Zamiast northowskiego, klasycznego już, podziału na instytucje formalne i nieformalne dokonują rozgraniczenia na instytucje włączające (ang. inclusive institutions), czyli te, które poszerzają krag uczestników procesów ekonomicznych i politycznych oraz wykluczające (ang. exclusive institutions) ${ }^{23}$, które działają w przeciwnym kierunku. Rzecz jasna, uznaja, że rozwojowi sprzyjaja te pierwsze, a jego możliwości ograniczają drugie. Korzystając z tej nomenklatury, kwestię sukcesów bądź porażek na drodze transformacji można byłoby sprowadzić do stwierdzenia, iż w krajach, którym udało się zreformować system gospodarczy, najwyraźniej w sposób skuteczny wprowadzono instytucje włączające, podczas gdy w pozostałych państwach próba ich implementacji nie powiodła się. Wyjaśnienie przyczyn tego powodzenia lub porażki jest już jednak znacznie trudniejsze. W zasadzie, co z kolei byłoby zgodne z wymową koncepcji path dependence, Acemoglu i Robinson akcentują duże znaczenie instytucjonalnego „bagażu” z przeszłości oraz fakt, iż o powodzeniu reform częstokroć decydujące moga być drobne i z pozoru nieistotne różnice czy wręcz przypadkowe koincydencje zdarzeń. Możliwość dokonania zmian struktury instytucjonalnej otwiera się, ich zdaniem, jedynie raz na jakiś czas, w okresach, które można by określić jako historyczne punkty zwrotne (ang. critical junctures), ale próby dokonania zmian nie zawsze, a właś-

${ }^{20}$ We wszystkich krajach tej grupy istniały możliwości nawiązania do wcześniejszych, przedsocjalistycznych doświadczeń z demokracją i wolnym rynkiem.

21 Zasadnicze idee przedstawione w tej pracy przybliżył polskim czytelnikom R. Matera [Matera, 2014].

22 Odrzucają również wytłumaczenia odwołujące się do warunków geograficznych i poziomu ,urynkowienia" gospodarki [Acemoglu, Robinson, 2013, rozdz. 2.].

${ }^{23} \mathrm{~W}$ polskim przekładzie tej pracy angielski termin exclusive institutions został niezbyt trafnie przetłumaczony jako instytucje aysyskeujace. 
ciwie stosunkowo rzadko, są owocne. Z tego względu kierunek i ostateczny efekt zmian jest niestety bardzo trudny do przewidzenia.

\section{Podsumowanie}

Teoria ekonomiczna, rozumiana jako pewien system czy zbiór poglądów dotyczących gospodarczego aspektu ludzkiej aktywności, nie może dać wyczerpujących odpowiedzi na pytania związane $z$ tak złożonym $i$ wielowymiarowym procesem, jak transformacja ustrojowa. Kwestia zarówno samego faktu rozpoczęcia się procesu transformacji ustrojowej krajów Europy Środkowej i Środkowo-Wschodniej, jak i przewidzenia kierunku, w jakim się ona potoczy, leżała poza możliwościami predykcyjnymi teorii ekonomii, w równej mierze ortodoksyjnej, jak i szkół pozostających poza głównym nurtem badań ekonomicznych.

Proces transformacji ustrojowej krajów Europy Środkowej i Środkowo-Wschodniej stanowi zaś doskonały przykład ukazujący trudności zachodzące we wszystkich tych sytuacjach, kiedy rozwiązując realne problemy społeczno-gospodarcze, odwołujemy się do teorii ekonomicznej. Ten konkretny przykład jest tym bardziej interesujący, że zasadniczą kwestię można bez trudu przedstawić jako problem typowo ekonomiczny: jak zminimalizować koszty osiagnięcia określonego celu (tu: przekształcenia systemu politycznego i gospodarczego w kierunku demokracji i gospodarki wolnorynkowej). Przy takim ujęciu fundamentalnego znaczenia nabiera stworzenie metody oszacowania tychże kosztów, co samo w sobie wydaje się niełatwe ${ }^{24}$, ale zadanie to staje się zupełnie karkołomne, jeśli uzmysłowimy sobie, że przy opartym na tego rodzaju kalkulacji wyborze ścieżek transformacji w istocie potrzebowalibyśmy obliczenia tychże kosztów na samym początku całego procesu. Tymczasem, wbrew temu, co zdają się sugerować niektórzy badacze życia gospodarczego i analitycy gospodarczy [np. Lazear, 2000], prognozowanie zmian kategorii ekonomicznych jest wyzwaniem nawet w przypadku gospodarek o względnie stabilnej strukturze instytucjonalnej. Co więcej, przy odwoływaniu się do analiz ekonomicznych jako źródła wskazówek dotyczących rozwiązywania problemów praktycznych warto pamiętać, iż teoria ekonomiczna obejmuje zaledwie pewien wycinek rzeczywistości społecznej, a w odniesieniu do większości (jeśli nie wszystkich) problemów społeczno-gospodarczych, w tym oczywiście również poszukiwania optymalnej ścieżki transformacji, mniejszą czy większą rolę odgrywają wszystkie elementy składające się na strukturę społeczna. Zatem, jeśli nawet istnialaby jakaś ekonomiczna teoria transformacji, pomoc z jej strony siła rzeczy byłaby ograniczona. To z kolei prowadzi do wniosku, iż ocenianie wkładu teorii ekonomicznych w wyjaśnienie procesu transformacji na podstawie zaleceń i wskazówek formułowanych przez ekonomistów będących reprezentantami poszczególnych nurtów byłoby nieuzasadnione. Przy (dyskusyjnym) założeniu, iż wskazanie optymalnej

\footnotetext{
${ }^{24} \mathrm{Na}$ dobrą sprawę należałoby również uwzględnić koszty alternatywne (koszty utraconych możliwości) i koszty społeczne (ubytki użyteczności wynikające ze zmiany systemu).
} 
ścieżki transformacji na podstawie rozważań teoretycznych byłoby w ogóle możliwe, podstawę do sformułowania tego rodzaju rozwiązania musiałaby stanowić raczej jakaś ogólna nauka społeczna, pozwalająca uchwycić wszelkie zależności zachodzące między płaszczyznami a komponentami życia społecznego.

Natomiast kwestia objaśnienia przebiegu i wytłumaczenia zróżnicowania faktycznie obranych przez państwa byłego bloku wschodniego ścieżek transformacji ma o tyle inny charakter, że w tym przypadku staramy się wyjaśnić wydarzenia, które już miały miejsce. Wychodzenie poza tradycyjnie pojmowany obszar badań ekonomicznych nadal wydaje się niezbędne, ale jest zdecydowanie łatwiejsze, ponieważ dysponujemy już wówczas określonym materiałem, który pozwala zawęzić pole możliwych do zakładania zależności pomiędzy zmiennymi, które wydają nam się istotne. Stąd i w tym przypadku można stwierdzić, iż zdecydowanie większy wkład w wyjaśnienie procesu transformacji ustrojowej krajów byłego bloku wschodniego wniosła ekonomia heterodoksyjna, a w szczególności te nurty nauk ekonomicznych, na gruncie których powstawały teorie, koncepcje i narzędzia analityczne pozwalające uchwycić związki pomiędzy wymiarem: ekonomicznym, społecznym, politycznym, kulturowym czy w końcu etycznym dokonujących się przemian.

\section{Literatura}

Acemoglu D., Robinson J. A. 2013 Why Nations Fail. The Origins of Power, Prosperity and Poverty, Crown Publishers, London (wyd. polskie: Dlaczego narody przegrywaja. Źródta władsy, pomyślności i ubóstwa, tłum. J. Łoziński, Wydawnictwo Zysk i S-ka, Poznań 2014).

Arthur B. 1989 Competing Technologies, Increasing Returns, and Lock-In by Historical Small Events, „Economic Journal”, no. 1.

Aspromourgos T. 1986 On the Origin of the Term Neoclassical, „Cambridge Journal of Economics", vol. 10, no. 30.

Colander D. C. 2000 The Death of Neoclassical Economics, "Journal of the History of Economic Thought", vol. 22, no. 2.

David P. 1985 Clio and the Economics of QWERTY, „American Economic Review”, vol. 75 , no. 2 .

Dzionek-Kozłowska J. 2009 Transformacja ustrojowa zperspektyny koncepiji path dependence, „Ekonomia”, vol. 3.

Dzionek-Kozłowska J. 2010 Rynek versus panstwo w swietle dyskusji o path dependence, „Ekonomia i Prawo”, vol. 6.

Galbraith J. K. 1990 The Rush to Capitalism, „The New York Review of Books”, 25th October.

Godłów-Legiędź J. 1989 Z historii sporu o racjonalność gospodarki socjalistycznej, „Ekonomista", nr 5-6.

Godłów-Legiędź J. 2010 Wspótczesna ekonomia. Ku nowemu paradygmatowi?, Wydawnictwo C. H. Beck, Warszawa. 
Hodgson G.M. 2007 Evolutionary and Institutional Economics as the New Mainstream?, „Evolutionary and Institutional Economic Review”, vol. 4, no. 1.

Huntington S. 2008 Zderzenie cywilizacji i nowy ksztatt ładu swiatowego, Warszawskie Wydawnictwo Literackie Muza, Warszawa.

Hurwicz L. 1973 The design of mechanisms for resource allocation, „American Economic Review", vol. 63, no. 2.

Hurwicz L. 1979 Socialism and Incentives: Developing a Framework, ,Journal of Comparative Economics", vol. 3, no. 3.

Kostro K. 2001 Hayek kontra socjalizm. Debata socjalistyczna a rozwój teorii społeczno-ekonomicznych Friedricha Augusta von Hayeka, „DiG”, Warszawa.

Kyriazis N.C., Zouboulakis M.S. 2005 Modeling institutional change in transition economies, „Communist and Post-Communist Studies”, vol. 38, no. 1.

Landes D. S. 1998 The Wealth and Poverty of Nations: Why Some Are So Rich and Some So Poor, W. W. Norton, New York (wyd. polskie: 2000 Bogactwo i nedza narodów. Dlaczego jedni sa tak bogaci, a inni tak ubodzy, tłum. H. Jankowska, Warszawskie Wydawnictwo Literackie Muza, Warszawa).

Lazear, E.P. 2000 Economic Imperialism, „Quarterly Journal of Economics”, vol. 115, no. 1.

Legiędź T. 2013 Nowa ekonomia instytucjonalna a zmiany paradygmatu rozwoju gospodarczego, „Ekonomia”, nr 4.

Liebowitz S. J., Margolis S.E. 1990 The Fable of the Keys, ,Journal of Law and Economics", vol. 33, no. 1.

Liebowitz S. J., Margolis S.E. 1995 Path Dependence, Lock-In, and History, ,Journal of Law, Economics and Organization", vol. 11, no. 1.

Maślak E. 2000 Paradygmat ekonomii ewolucyjnej, „Gospodarka Narodowa”, nr 1-2.

Matera R. 2014 Studia nad bogactwem i ubóstwem narodów na przełomie mileniów - wklad Darona Acemoglu i Jamesa A. Robinsona, ,Ruch prawniczy, ekonomiczny i socjologiczny", vol. 76, nr 1.

Nelson R. R., Winter S. G. 1982 An Evolutionary Theory of Economic Change, W. W. Norton, Cambridge, MA, London.

North D. C. 1990 Institutions, Institutional Change and Economic Performance, Cambridge University Press, Cambridge.

North D. C. 1991 Institutions, ,Journal of Economic Perspectives”, vol. 5, no. 1.

North D. C. 2010 Understanding the Process of Institutional Change, Princeton University Press, Princeton.

Olson M. 1982 The Rise and Decline of Nations: Economic Growth, Stagflation, and Social Rigidities, Yale University Press, New Haven, London.

Olson M. 1992 The Hidden Path to a Successful Economy, [in:] The Emergence of Market Economies in Eastern Europe, C. Clague, G. C. Rausser (eds.), Blackwell, Cambridge.

Puffert D. J. 2004 Path Dependence, Network Form and Technological Change, [in:] History Matters: Essays on Economic Growth, Technology and Demographic Change, W. Sundstrom, T. Guinnane, W. Whatley (eds.), Stanford University Press, Stanford.

Snowdon B., Vane H., Wynarczyk P. 1998 Wspótczesne nurty teorii makroekonomii, Wydawnictwo Naukowe PWN, Warszawa. 
Snowdon B., Vane H. 2005 Modern macroeconomics. Its origins, development and current state, E. Elgar, Cheltenham UK, Northampton MA.

Teoria myboru publicznego. Glówne nurty i zastosowania, J. Wilkin (red.), Wydawnictwo Naukowe Scholar, Warszawa.

Wilkin J. 1995 Jaki kapitalizm, jaka Polska?, Wydawnictwo Naukowe PWN, Warszawa.

Wilkin J. 2012 Teoria wyboru publicznego - bomo oeconomicus w sferze polityki, [w:] Teoria wyboru publicznego. Glówne nurty $i$ zastosowania, J. Wilkin (red.), Wydawnictwo Naukowe Scholar, Warszawa.

Williamson J. 1990 What Washington Means by Policy Reform, [in:] Latin American Adjustment: How Much Has Happened? , J. Williamson (ed.), Institute for International Economics, Washington.

Williamson J. 2005 The Strange History of the Washington Consensus, „Journal of PostKeynesians Economics", vol. 27, no. 2.

Winiecki J. 2004 Determinants of Catching up or Falling Behind. Interaction of Formal and Informal Institutions, „Post-Communies Economies”, vol. 16, no. 2.

Winiecki J. 2012 Transformacja postkomunistyczna. Studium praypadku zmian instytucjonalnych, Wydawnictwo C. H. Beck, Warszawa.

Zukowski R. 2005 Routes out of Socialism as Path-Dependent Process: Central Europe's Experiences and Lessons for Cuba, „Cuba in Transition”, vol. 15.

Zweynert J., Goldschmidt N. 2006 The Two Transitions in Central and Eastern Europe, „Journal of Economic Issues", vol. 15, no. 4. 